\title{
Sistem Pendukung Keputusan Pemilihan Karyawan Terbaik Parking Area Menerapkan Metode MOORA
}

\author{
Mesran*, Riski Ferita Wahyu, Febrianus Gea, \\ Prodi Teknik Informatika, Fakultas Ilmu Komputer dan Teknologi Informasi, Univ. Budi Darma, Medan, Indonesia \\ Email: ${ }^{1, *}$ mesran.skom.mkom@gmail.com, ${ }^{2}$ riskiutama25@gmail.com, ${ }^{3}$ Boygea99@ gmail.com,
}

INFORMASI ARTIKEL

Sejarah Artikel:

Diterima Redaksi : 10 Oktober 2021

Revisi Akhir : : 1 November 2021

Diterima : 20 November 2021

Diterbitkan Online : 28 November 2021

\author{
KATA KUNCI \\ SPK; Karyawan Terbaik; Parking \\ Area; MOORA \\ SPK; Karyawan Terbaik; Parking \\ Area; MOORA
}

KORESPONDENSI

E-mail:

mesran.skom.mkom@gmail.com

\begin{abstract}
A B S T $\mathbf{R}$ A $\mathbf{C}$ T
Abstrak-Karyawan merupakan bagian aset penting yang dimiliki sebuah perusahaan dalam mempertahakan kelangsungan hidup serta kemampuan dalam bersaing. Dalam hal ini seorang karyawan harus memiliki skill bahkan keterampilan untuk menungkatkan bisnis dalam perusahaan. Supaya kinerja Karyawan menjadi lebih baik, maka dibutuhkan suatu sistem dalam membantu pemilihan Karyawan terbaik, dibutuhkan suatu Sistem Pendukung Keputusan. Multi Objective Optimization on the Basic of Ratio Analysis (MOORA) adalah salah satu metode yang mendukung yang bertujuan untuk menentukan alternatif terbaik yang sesuai dengan kriteria menurut persyaratan Karyawan terbaik di PT. Centrepark Citra Corpora tersebut. Dalam menentukan calon yang layak menjadi Karyawan terbaik menurut rumus serta metode yang digunakan, sehingga diperoleh nilai alternatif terbaik sebesar 0.39192 atas nama Moethar Situmeang.
\end{abstract}

Abstract- Employees are an important part of a company's assets in maintaining its survival and ability to compete. In this case, an employee must have the skills and even the skills to improve business within the company. In order for employee performance to be better, a system is needed to assist the selection of the best employees, a decision support system is needed. Multi Objective Optimization on the Basic of Ratio Analysis (MOORA) is one of the supporting methods that aims to determine the best alternative that fits the criteria according to the requirements of the best employees at PT. The Citra Corpora Centrepark. In determining the candidate who deserves to be the best employee according to the formula and method used, in order to obtain the best alternative value of 0.39192 on behalf of Moehar Situmeang.

\section{PENDAHULUAN}

Karyawan merupakan bagian aset penting yang dimiliki sebuah perusahaan dalam mempertahakan kelangsungan hidup, berkembang, kemajuan, serta kemampuan dalam bersaing dan mendapatkan laba dari hasil kinerja yang ditorehkan dan dikerjakan oleh karyawan. Dalam perkembangan bisnis yang semakin pesat dan kompetetif, persaingan perusahaan semakin meningkat[1].

Pemilihan karyawan terbaik merupakan suatu hal yang sangat diharapkan tentunya di kalangan perusahaan baik swasta maupun negeri, agar dapat mengetahui perkembangan perusahaan dalam hal ini peran karyawan sangatlah dibutuhkan untuk menjamin kualitas perusahaan. Dalam hal ini tentunya di perusahaan PT . Centrepark Citra Corpora dalam pemilihan karyawan terbaik di bagian parking area terkendala, dikarenakan banyaknya karyawan yang mendaftar namun tidak memenuhi kriteria perusahaan yang telah ditentukan misalnya skil (keahlian), kemampuan kosakata, serta lulusan terbaik. Oleh karena itu melalui permasalahn diatas dibutuhkan suatu sistem untuk meminimalisir dan memperoleh data yang lebih akurat[2].

Maka dari itu dibutuhkan suatu Sistem Pendukung Keputusan (SPK) yang mampu mengolah data karyawan agar menghasilkan sebuah nilai kesimpulan yang lebih efektif dan efisien dalam menentukan karyawan yang dianggap baik dan berkualitas dan berkompeten dibidangnya. Adapun metode penelitian yang digunakan yaitu Multi-Objective Optimization on Basis of Ratio Analysis (MOORA). Metode MOORA adalah metode yang memiliki perhitungan dengan kalkulasi yang minimun dan sangat sederhana. Metode ini memiliki tingkat selektifitas yang baik dalam menentukan 
suatu alternatif. Pendekatan yang dilakukan MOORA didefenisikan sebagai suatu proses secara bersamaan guna mengoptimalkan dua atau lebih yang saling bertentangan pada beberapa kendala[3].

Beberapa penelitian sebelumnya yang terkait dengan penerapan metode Multi-Objective Optimization on Basis of Ratio Analysis (MOORA) yang memungkinkan proses dalam pengambilan suatu keputusan, serta meminimumkan perhitungan yang lebih sederhana dan mampu mendapatkan hasil yang lebih akurat, diantaranya penelitian yang dilakukan oleh Novi Lestari pada tahun 2021 tentang penerimaan Dosen terbaik menggunakan metode MOORA yang dimana terdapat lima kriteria yang dijadikan dasar perhitungan yaitu jenjang pendidikan, IPK, pengalaman, kompetensi, dan usia. Dan setelah dilakukan normalisasi maka diperolehlah hasil nilai tertinggi dari salah seorang dosen dengan bobot nilai 0.465504 dan menduduki peringkat pertama[4]. Penelitian yang dilakukan oleh Lugina Ismi Muhammad pada tahun 2020 tentang pemilihan calon terbaik dengan menggunakan Metode MOORA dimana yang menjadi kriteria pertama adalah nilai rapot, Kriteria kedua jumlah penghasilan orangtua, kriteria ketiga adalah jumlah tanggungan orangtua, dan kriteria keempat adalah keadaan orangtua. Dan hasil yang diperoleh setelah dilakukan normalisasi adalah dengan bobot nilai 0.257829 sebagai peringkat pertama[5]. Penelitian yang dilakukan oleh Samuel Manurung pada tahun 2018 membahas tentang pemilihan Karyawan terbaik menggunakan metode MOORA yang memperoleh hasil nilai tertinggi dari salah seorang Karyawan dengan bobot nilai 9.95 sebagai peringkat pertama[6]. Penelitian yang dilakukan oleh Titania Geovanka pada tahun 2021 tentang pemilihan buah merah terbaik dengan metode MOORA dimana terdapat empat kriteria diantaranya, harga, berat $(\mathrm{kg})$, lebar(L), panjang(P). Dan setelah dilakukan normalisasi maka diperolehlah hasil tertinggi dengan bobot nilai 76.100 dan menduduku peringkat pertama[7].

Dari pembahasan di atas penulis tertarik untuk melakukan penelitian pada PT . Centrepark Citra Corpora dengan menggunakan metode Multi-Objective Optimization on Basis of Ratio Analysis (MOORA) untuk memperoleh data-data dalam menentukan kriteria karyawan terbaik. Penerapan metode MOORA diharapkan memberikan manfaat untuk dapat diperoleh nilai alternatif optimal dari jumlah alternatif dan kriteria tertentu yang kemudian dilanjutkan dengan proses perangkingan. Penilaian yang berdasarkan kriteria-kriteria yang sudah dijelaskan diatas diharapkan mampu mendapatkan hasil yang lebih tepat dan akurat.

\section{METODOLOGI PENELITIAN}

\subsection{Tahapan Penelitian}

Ada beberapa tahapan yang dilakukan dalam penelitian ini, yaitu:

1. Tahapan wawancara, dalam tahapan ini peneliti melakukan wawancara terhadap salah satu bagian dari karyawa PT. Centrepark Citra Corpora

2. Tahapan pengumpulan data, dalam tahapan ini peneliti melakukan pengumpulan data Karyawan yang selanjutnya dijadikan sebagai alternatif.

3. Tahapan pemilihan Karyawan terbaik, dalam tahapan ini peneliti menggabungkan data-data Karyawan yang ini dilakukan suatu pemilihan Karyawan terbaik melalui beberapa alternatif yang ada.

4. Tahapan Implementasi metode MOORA, dalam tahapan ini peneliti menggunakan metode MOORA dalam melakukan suatu perhitungan pada setiap alternatif dan kriteria yang ada untuk memperoleh alternatif terbaik.

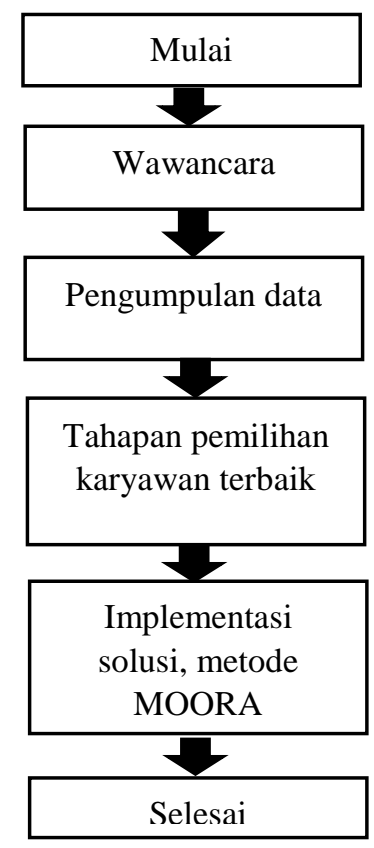

Gambar 1. Tahapan Penelitian 


\subsection{Karyawan Terbaik}

Karyawan terbaik adalah seorang pekerja yang di suatu perusahaan ataupun lembaga yang memiliki pendidikan, kecerdasan ataupun keahlian dibidangnya dalam melakukan operasional pada tempat perusahaan dia bekerja. Dan hanya karyawan terbaiklah yang memiliki kriteria khusus yang dapat direkomendasikan menjadi karyawan terbaik[8].

\subsection{Sistem Pendukung Keputusan}

Sistem pendukung keputusan (SPK) adalah salah satu cara mengorganisir informasi yang dimaksudkan untuk digunakan dalam membuat keputusan. Ada yang mendefinisikan bahwa sistem pendukung keputusan merupakan suatu pendekatan untuk mendukung pengambilan keputusan. Sistem pendukung keputusan menggunakan data, memberikan antarmuka pengguna yang mudah dan dapat menggabungkan pemikiran pengambilan keputusan[9]-[11].

\subsection{Metode Multi Objective Optimization on the Basic of Ratio Analysis (MOORA)}

Multi Objective Optimization on the Basic of Ratio Analysis (MOORA) merupakan metode yang diperkenalkan oleh Brauers dan Zavadkas (2006). Metode yang terbilang baru ini pertama kali digunakan oleh Brauers dalam suatu pengambilan keputusan dengan multi kriteria. Keunggulan metode MOORA yaitu sangat sederhana, stabil, dan kuat, bahkan metode ini tidak membutuhkan seseorang yang ahli di bidang matematika. Metode MOORA ini diharapkan dapat memberikan hasil yang baik dalam membantu penentuan keputusan[12]-[18]. Adapun langkah-langkah dalam penyelesaian masalah menggunakan metode MOORA[19], sebagai berikut:

1. Menentukan matriks keputusan dengan alternatif sebagai baris, dan kriteria sebagai kolom.

Keterangan:

$$
x_{i j}=\left[\begin{array}{ccc}
x_{11} & x_{12} & x_{1 n} \\
x_{21} & x_{22} & x_{2 n} \\
x_{m 1} & x_{m 2} & x_{m n}
\end{array}\right]
$$

Xij : Matriks keputusan alternatif i pada kriteria j

i : Alternatif (baris)

j : Attribut atau kriteria (kolom)

n : Jumlah atribut/kriteria

$\mathrm{m}$ : Jumlah alternatif/baris

2. Menentukan matriks normalisasi pada persamaan berikut:

$$
x_{i j}^{*}=\frac{x_{i j}}{\sqrt{\sum_{i=1}^{m} x_{i j}^{2}}}
$$

Keterangan:

Xij : Matriks keputusan alternatif i pada kriteria j

i : Alternatif (baris)

j : Attribut atau kriteria (kolom)

m : Jumlah Alternatif/baris

$\mathrm{X} * \mathrm{ij}$ : Matriks normalisasi pada alternatif i pada kriteria $\mathrm{j}$

3. Menentukan Matriks normalisasi terbobot:

Keterangan:

$$
y_{i}^{*}=\sum_{j=1}^{g} x_{i j}^{*}-\sum_{i=g+1}^{n} x_{i j}^{*}
$$

$x_{i j}^{*} \quad$ : Matriks normalisasi pada alternatif i pada kriteria $\mathrm{j}$

j : Attribut atau kriteria (kolom)

i : Alternatif (baris) jumlah tipe kriteria

g : Jumlah attribut/kriteria/kolom dengan kriteria benefit

n : Jumlah attribut/kriteria/kolom

yi : Nilai optimasi pada alternatif i

4. Menentukan nilai preferensi atau perangkingan yang dilakukan dengan cara mengurutkan nilai optimasi setiap alternatif dari nilai tertinggi ke nilai terendah. Alternatif dengan nilai optimasu tertinggi merupakan alternatif terbaik.

\section{HASIL DAN PEMBAHASAN}

\subsection{Penentuan Kriteria dan bobot}

Dalam menghasilkan suatu keputusan dalam menentukan pemilihan karyawan terbaik di Pt. Centrepark Citra Corpora, maka dibutuhkan beberapa data karyawan serta kriteria, bobot dan alternatif. Untuk itu terdapat 10 alternatif dan 5 (lima) kriteria yang digunakan dalam melakukan suatu penilaian. Maka dari itu di berbagai kriteria dalam pemilihan nilai bobot yang dimana hasilnya diperoleh dari pembobotan metode Rank Order Centroid (ROC). Berikut tabel 1 merupakan daftar karyawan. 
Tabel 1. Alternatif Karyawan

\begin{tabular}{cc}
\hline Alternatif & Nama Karyawan \\
\hline A1 & Khairul Anhar \\
A2 & Vivi Elvina Simanjuntak \\
A3 & Rahmad Hidayat \\
A4 & Rudi Hermansyah Bako \\
A5 & Ricky Syahputra \\
A6 & Rudi Sidabutar \\
A7 & Chandra Mualim Putra \\
A8 & Muhammad Soufi \\
A9 & Moethar Situmeang \\
A10 & Agustin Rahmawati \\
\hline
\end{tabular}

Tabel 2. Kriteria

\begin{tabular}{cccc}
\hline Kriteria & Keterangan & Bobot & Jenis \\
\hline C1 & Kedisiplinan & 0.34 & Benefit \\
C2 & Kerjasama Tim & 0.21 & Benefit \\
C3 & Sikap & 0.15 & Benefit \\
C4 & Kehadiran & 0.11 & Benefit \\
C5 & Skill & 0.08 & Benefit \\
C6 & Loyalitas & 0.05 & Benefit \\
C7 & Masa Kerja & 0.03 & Benefit \\
C8 & Produktifitas & 0.02 & Benefit \\
\hline
\end{tabular}

Pada tabel 2 di atas, bobot pada tiap-tiap kriteria diperoleh dari metode Rank Order Centroid (ROC)[20]-[22]. Keterangan pada tabel 2, dapat dilihat sebagai berikut.

Kedisiplinan

Kerjasama Tim

Sikap

Kehadiran

Skill

Loyalitas

Masa Kerja

Produktifitas

: Tindakan karyawan dalam melakukan peraturan yang ditetapkan perusahaan.

: Merupakan bagaimana karyawan berkolaborasi dan bersatu bekerja sama untuk mencapai tujuan kinerja tim.

: Suatu reaksi atau attitude seseorang sebagai suatu reaksi pandangan dan kesopanan.

: Absensi seorang karyawan yang bekerja sebagai bukti kehadiran.

: Keahlian yang dimiliki karyawan menggunakan akal, pikiran dan ide yang kreatif.

: Merupakan suatu pengabdian, kesetian, dan kepercayaan yang diberikan kepada seseorang.

: Yaitu jangka waktu atau lamanya seorang karyawan bekerja pada suatu instansi.

: Hasil efektifitas dan efisien yang dilakukan oleh karyawan atas pencapaian tujuan terhadap perusahaaan dengan sumber daya yang digunakan.

Tabel berikut merupakan pembobotan untuk kriteria Kedisiplinan $\left(\mathrm{C}_{1}\right)$

Tabel 3. Pembobotan Kriteria Kedisiplinan $\left(C_{1}\right)$

\begin{tabular}{cc}
\hline Keterangan & Bobot \\
\hline Sangat Baik & 4 \\
Baik & 3 \\
Cukup & 2 \\
Buruk & 1 \\
\hline
\end{tabular}

Tabel berikut merupakan pembobotan untuk kriteria Kerjasama Tim $\left(\mathrm{C}_{2}\right)$

Tabel 4. Pembobotan Kerjasama Tim $\left(\mathrm{C}_{2}\right)$

\begin{tabular}{cc}
\hline Keterangan & Bobot \\
\hline Sangat Baik & 4 \\
Baik & 3 \\
Cukup & 2 \\
Buruk & 1 \\
\hline
\end{tabular}

Tabel berikut merupakan pembobotan untuk kriteria Sikap $\left(\mathrm{C}_{3}\right)$

Tabel 5. Pembobotan Sikap $\left(\mathrm{C}_{3}\right)$

\begin{tabular}{cc}
\hline Keterangan & Bobot \\
\hline Sangat Baik & 4 \\
Baik & 3
\end{tabular}




\begin{tabular}{cc} 
Cukup & 2 \\
Buruk & 1 \\
\hline
\end{tabular}

Tabel berikut merupakan pembobotan untuk kriteria Kehadiran $\left(\mathrm{C}_{4}\right)$

Tabel 6. Pembobotan Kehadiran $\left(\mathrm{C}_{4}\right)$

\begin{tabular}{cc}
\hline Keterangan & Bobot \\
\hline Sangat Baik & 4 \\
Baik & 3 \\
Cukup & 2 \\
Buruk & 1 \\
\hline
\end{tabular}

Tabel berikut merupakan pembobotan untuk kriteria Skill $\left(\mathrm{C}_{5}\right)$

Tabel 7. Pembobotan Skill $\left(\mathrm{C}_{5}\right)$

\begin{tabular}{cc}
\hline Keterangan & Bobot \\
\hline Sangat Baik & 4 \\
Baik & 3 \\
Cukup & 2 \\
Buruk & 1 \\
\hline
\end{tabular}

Tabel berikut merupakan pembobotan untuk kriteria Loyalitas $\left(\mathrm{C}_{6}\right)$

Tabel 8. Pembobotan Loyalitas $\left(\mathrm{C}_{6}\right)$

\begin{tabular}{cc}
\hline Keterangan & Bobot \\
\hline Sangat Baik & 4 \\
Baik & 3 \\
Cukup & 2 \\
Buruk & 1 \\
\hline
\end{tabular}

Tabel berikut merupakan pembobotan untuk kriteria Produktifitas $\left(\mathrm{C}_{8}\right)$

Tabel 9. Pembobotan Produktifitas $\left(\mathrm{C}_{8}\right)$

\begin{tabular}{cc}
\hline Keterangan & Bobot \\
\hline Sangat Bagus & 4 \\
Bagus & 3 \\
Cukup & 2 \\
Kurang & 1 \\
\hline
\end{tabular}

Berikut nilai dari Alternatif untuk kriteria

Tabel 6. Alternatif Untuk Kriteria

\begin{tabular}{|c|c|c|c|c|c|c|c|c|}
\hline Alternatif & $\mathrm{C}_{1}$ & $\mathrm{C}_{2}$ & $\mathrm{C}_{3}$ & $\mathrm{C}_{4}$ & $\mathrm{C}_{5}$ & $\mathrm{C}_{6}$ & $\mathrm{C}_{7}$ & $\mathrm{C}_{8}$ \\
\hline $\mathrm{A}_{1}$ & $\begin{array}{c}\text { Sangat } \\
\text { Baik }\end{array}$ & $\begin{array}{c}\text { Sangat } \\
\text { Baik }\end{array}$ & Baik & $\begin{array}{c}\text { Sangat } \\
\text { Baik }\end{array}$ & $\begin{array}{l}\text { Sangat } \\
\text { Baik }\end{array}$ & $\begin{array}{c}\text { Sangat } \\
\text { Baik }\end{array}$ & 7 & $\begin{array}{l}\text { Sangat } \\
\text { Bagus }\end{array}$ \\
\hline $\mathrm{A}_{2}$ & Baik & Baik & Cukup & Baik & Baik & Baik & 5 & Bagus \\
\hline $\mathrm{A}_{3}$ & Cukup & Baik & $\begin{array}{c}\text { Sangat } \\
\text { Baik }\end{array}$ & Baik & Cukup & Cukup & 4 & Cukup \\
\hline $\mathrm{A}_{4}$ & Cukup & Cukup & Baik & $\begin{array}{c}\text { Sangat } \\
\text { Baik }\end{array}$ & $\begin{array}{c}\text { Sangat } \\
\text { Baik }\end{array}$ & Baik & 3 & Bagus \\
\hline $\mathrm{A}_{5}$ & Baik & Baik & Cukup & Baik & Baik & Cukup & 2 & Cukup \\
\hline $\mathrm{A}_{6}$ & Baik & Sangat baik & Baik & Cukup & Baik & Cukup & 4 & Cukup \\
\hline $\mathrm{A}_{7}$ & Cukup & Cukup & Baik & Baik & $\begin{array}{c}\text { Sangat } \\
\text { Baik }\end{array}$ & Buruk & 2 & Kurang \\
\hline $\mathrm{A}_{8}$ & Baik & $\begin{array}{c}\text { Sangat } \\
\text { Baik }\end{array}$ & Baik & Cukup & Baik & Baik & 4 & Bagus \\
\hline $\mathrm{A}_{9}$ & $\begin{array}{c}\text { Sangat } \\
\text { Baik }\end{array}$ & $\begin{array}{c}\text { Sangat } \\
\text { Baik }\end{array}$ & $\begin{array}{c}\text { Sangat } \\
\text { Baik }\end{array}$ & Baik & Baik & Cukup & 6 & Cukup \\
\hline $\mathrm{A}_{10}$ & $\begin{array}{c}\text { Sangat } \\
\text { Baik }\end{array}$ & Cukup & Baik & $\begin{array}{c}\text { Sangat } \\
\text { Baik }\end{array}$ & Cukup & Baik & 5 & Bagus \\
\hline
\end{tabular}


Berikut nilai dari rating kecocokan antara alternatif dan kriteria

Tabel 7. Rating Kecocokan antara Alternatif dan Kriteria

\begin{tabular}{lcccccccc}
\hline Alternatif & $\mathrm{C}_{1}$ & $\mathrm{C}_{2}$ & $\mathrm{C}_{3}$ & $\mathrm{C}_{4}$ & $\mathrm{C}_{5}$ & $\mathrm{C}_{6}$ & $\mathrm{C}_{7}$ & $\mathrm{C}_{8}$ \\
\hline $\mathrm{A}_{1}$ & 4 & 4 & 3 & 4 & 4 & 4 & 7 & 4 \\
$\mathrm{~A}_{2}$ & 3 & 3 & 2 & 3 & 3 & 3 & 5 & 3 \\
$\mathrm{~A}_{3}$ & 2 & 3 & 4 & 3 & 2 & 2 & 4 & 2 \\
$\mathrm{~A}_{4}$ & 2 & 2 & 3 & 4 & 4 & 3 & 3 & 3 \\
$\mathrm{~A}_{5}$ & 3 & 3 & 2 & 3 & 3 & 2 & 2 & 2 \\
$\mathrm{~A}_{6}$ & 3 & 4 & 3 & 2 & 3 & 2 & 4 & 2 \\
$\mathrm{~A}_{7}$ & 2 & 2 & 3 & 3 & 4 & 1 & 2 & 1 \\
$\mathrm{~A}_{8}$ & 3 & 4 & 3 & 2 & 3 & 3 & 4 & 3 \\
$\mathrm{~A}_{9}$ & 4 & 4 & 4 & 3 & 3 & 2 & 6 & 2 \\
$\mathrm{~A}_{10}$ & 4 & 2 & 3 & 4 & 2 & 3 & 5 & 3 \\
\hline
\end{tabular}

\subsection{Perhitungan Menggunakan Metode MOORA}

Berikut ini adalah langkah-langkah yang digunakan untuk memperoleh rating kecocokan menggunakan metode MOORA (Multi Objective Optimization on The Basic of Ratio Analysis):

1. Mempersiapkan Matrik Keputusan

Tabel 8. Matrik Keputusan
$\left|\begin{array}{llllllll}4 & 4 & 3 & 4 & 4 & 4 & 7 & 4 \\ 3 & 3 & 2 & 3 & 3 & 3 & 5 & 3 \\ 2 & 3 & 4 & 3 & 2 & 2 & 4 & 2 \\ 2 & 2 & 3 & 4 & 4 & 3 & 3 & 3 \\ 3 & 3 & 2 & 3 & 3 & 2 & 2 & 2 \\ 3 & 4 & 3 & 2 & 3 & 2 & 4 & 2 \\ 2 & 2 & 3 & 3 & 4 & 1 & 2 & 1 \\ 3 & 4 & 3 & 2 & 3 & 3 & 4 & 3 \\ 4 & 4 & 4 & 3 & 3 & 2 & 6 & 2 \\ 4 & 2 & 3 & 4 & 2 & 3 & 5 & 3\end{array}\right|$

2. Normalisasi Matriks Keputusan

Untuk menentukan Kriteria $C_{1}$ (Kedisiplinan)

$X_{1,1}^{*}=\frac{4}{\sqrt{\left[4^{2}+3^{2}+2^{2}+2^{2}+3^{2}+3^{2}+2^{2}+3^{2}+4^{2}+4^{2}\right]}}=\frac{4}{\sqrt{96}}=\frac{4}{9.797}=0.408$

$X_{2,1}^{*}=\frac{3}{\sqrt{\left[4^{2}+3^{2}+2^{2}+2^{2}+3^{2}+3^{2}+2^{2}+3^{2}+4^{2}+4^{2}\right]}}=\frac{3}{\sqrt{96}}=\frac{3}{9.797}=0.306$

$X_{3,1}^{*}=\frac{2}{\sqrt{\left[4^{2}+3^{2}+2^{2}+2^{2}+3^{2}+3^{2}+2^{2}+3^{2}+4^{2}+4^{2}\right]}}=\frac{2}{\sqrt{96}}=\frac{2}{9.797}=0.204$

$X_{4,1}^{*}=\frac{2}{\sqrt{\left[4^{2}+3^{2}+2^{2}+2^{2}+3^{2}+3^{2}+2^{2}+3^{2}+4^{2}+4^{2}\right]}}=\frac{2}{\sqrt{96}}=\frac{2}{9.797}=0.204$

$X_{5,1}^{*}=\frac{3}{\sqrt{\left[4^{2}+3^{2}+2^{2}+2^{2}+3^{2}+3^{2}+2^{2}+3^{2}+4^{2}+4^{2}\right]}}=\frac{3}{\sqrt{96}}=\frac{3}{9.797}=0.306$

$X_{6,1}^{*}=\frac{3}{\sqrt{\left[4^{2}+3^{2}+2^{2}+2^{2}+3^{2}+3^{2}+2^{2}+3^{2}+4^{2}+4^{2}\right]}}=\frac{3}{\sqrt{96}}=\frac{3}{9.797}=0.306$

$X_{7,1}^{*}=\frac{2}{\sqrt{\left[4^{2}+3^{2}+2^{2}+2^{2}+3^{2}+3^{2}+2^{2}+3^{2}+4^{2}+4^{2}\right]}}=\frac{2}{\sqrt{96}}=\frac{2}{9.797}=0.204$

$X_{8,1}^{*}=\frac{3}{\sqrt{\left[4^{2}+3^{2}+2^{2}+2^{2}+3^{2}+3^{2}+2^{2}+3^{2}+4^{2}+4^{2}\right]}}=\frac{3}{\sqrt{96}}=\frac{3}{9.797}=0.306$

$X_{9,1}^{*}=\frac{4}{\sqrt{\left[4^{2}+3^{2}+2^{2}+2^{2}+3^{2}+3^{2}+2^{2}+3^{2}+4^{2}+4^{2}\right]}}=\frac{4}{\sqrt{96}}=\frac{4}{9.797}=0.408$

$X_{10,1}^{*}=\frac{4}{\sqrt{\left[4^{2}+3^{2}+2^{2}+2^{2}+3^{2}+3^{2}+2^{2}+3^{2}+4^{2}+4^{2}\right]}}=\frac{4}{\sqrt{96}}=\frac{4}{9.797}=0.408$

Untuk $C_{2}$ (Kerjasama Tim)

$X_{1,2}^{*}=\frac{4}{\sqrt{\left[4^{2}+3^{2}+3^{2}+2^{2}+3^{2}+4^{2}+2^{2}+4^{2}+4^{2}+2^{2}\right]}}=\frac{4}{\sqrt{103}}=\frac{4}{10.148}=0.394$

$X_{2,2}^{*}=\frac{3}{\sqrt{\left[4^{2}+3^{2}+3^{2}+2^{2}+3^{2}+4^{2}+2^{2}+4^{2}+4^{2}+2^{2}\right]}}=\frac{3}{\sqrt{103}}=\frac{3}{10.148}=0.295$

$X_{3,2}^{*}=\frac{3}{\sqrt{\left[4^{2}+3^{2}+3^{2}+2^{2}+3^{2}+4^{2}+2^{2}+4^{2}+4^{2}+2^{2}\right]}}=\frac{4}{\sqrt{103}}=\frac{4}{10.148}=0.295$

$X_{4,2}^{*}=\frac{2}{\sqrt{\left[4^{2}+3^{2}+3^{2}+2^{2}+3^{2}+4^{2}+2^{2}+4^{2}+4^{2}+2^{2}\right]}}=\frac{2}{\sqrt{103}}=\frac{2}{10.148}=0.197$

$X_{5,2}^{*}=\frac{3}{\sqrt{\left[4^{2}+3^{2}+3^{2}+2^{2}+3^{2}+4^{2}+2^{2}+4^{2}+4^{2}+2^{2}\right]}}=\frac{3}{\sqrt{103}}=\frac{3}{10.148}=0.295$ 
$X_{6,2}^{*}=\frac{4}{\sqrt{\left[4^{2}+3^{2}+3^{2}+2^{2}+3^{2}+4^{2}+2^{2}+4^{2}+4^{2}+2^{2}\right]}}=\frac{4}{\sqrt{103}}=\frac{4}{10.148}=0.394$
$X_{7,2}^{*}=\frac{2}{\sqrt{\left[4^{2}+3^{2}+3^{2}+2^{2}+3^{2}+4^{2}+2^{2}+4^{2}+4^{2}+2^{2}\right]}}=\frac{2}{\sqrt{103}}=\frac{2}{10.148}=0.197$
$X_{8,2}^{*}=\frac{4}{\sqrt{\left[4^{2}+3^{2}+3^{2}+2^{2}+3^{2}+4^{2}+2^{2}+4^{2}+4^{2}+2^{2}\right]}}=\frac{4}{\sqrt{103}}=\frac{4}{10.148}=0.394$
$X_{9,2}^{*}=\frac{4}{\sqrt{\left[4^{2}+3^{2}+3^{2}+2^{2}+3^{2}+4^{2}+2^{2}+4^{2}+4^{2}+2^{2}\right]}}=\frac{4}{\sqrt{103}}=\frac{2}{10.148}=0.394$
$X_{10,2}^{*}=\frac{2}{\sqrt{\left[4^{2}+3^{2}+3^{2}+2^{2}+3^{2}+4^{2}+2^{2}+4^{2}+4^{2}+2^{2}\right]}}=\frac{2}{10.148}=0.197$

Untuk $C_{3}$ (Sikap)

$X_{1,3}^{*}=\frac{3}{\sqrt{\left[3^{2}+2^{2}+4^{2}+3^{2}+2^{2}+3^{2}+3^{2}+3^{2}+4^{2}+3^{2}\right]}}=\frac{3}{\sqrt{94}}=\frac{3}{9.695}=0.309$

$X_{2,3}^{*}=\frac{2}{\sqrt{\left[3^{2}+2^{2}+4^{2}+3^{2}+2^{2}+3^{2}+3^{2}+3^{2}+4^{2}+3^{2}\right]}}=\frac{2}{\sqrt{94}}=\frac{2}{9.695}=0.206$

$X_{3,3}^{*}=\frac{4}{\sqrt{\left[3^{2}+2^{2}+4^{2}+3^{2}+2^{2}+3^{2}+3^{2}+3^{2}+4^{2}+3^{2}\right]}}=\frac{4}{\sqrt{94}}=\frac{4}{9.695}=0.412$

$X_{4,3}^{*}=\frac{3}{\sqrt{\left[3^{2}+2^{2}+4^{2}+3^{2}+2^{2}+3^{2}+3^{2}+3^{2}+4^{2}+3^{2}\right]}}=\frac{3}{\sqrt{94}}=\frac{3}{9.695}=0.309$

$X_{5,3}^{*}=\frac{2}{\sqrt{\left[3^{2}+2^{2}+4^{2}+3^{2}+2^{2}+3^{2}+3^{2}+3^{2}+4^{2}+3^{2}\right]}}=\frac{2}{\sqrt{94}}=\frac{2}{9.695}=0.206$

$X_{6,3}^{*}=\frac{3}{\sqrt{\left[3^{2}+2^{2}+4^{2}+3^{2}+2^{2}+3^{2}+3^{2}+3^{2}+4^{2}+3^{2}\right]}}=\frac{3}{\sqrt{94}}=\frac{3}{9.695}=0.309$

$X_{7,3}^{*}=\frac{3}{\sqrt{\left[3^{2}+2^{2}+4^{2}+3^{2}+2^{2}+3^{2}+3^{2}+3^{2}+4^{2}+3^{2}\right]}}=\frac{3}{\sqrt{94}}=\frac{3}{9.695}=0.309$

$X_{8,3}^{*}=\frac{3}{\sqrt{\left[3^{2}+2^{2}+4^{2}+3^{2}+2^{2}+3^{2}+3^{2}+3^{2}+4^{2}+3^{2}\right]}}=\frac{3}{\sqrt{94}}=\frac{3}{9.695}=0.309$

$X_{9,3}^{*}=\frac{4}{\sqrt{\left[3^{2}+2^{2}+4^{2}+3^{2}+2^{2}+3^{2}+3^{2}+3^{2}+4^{2}+3^{2}\right]}}=\frac{4}{\sqrt{94}}=\frac{4}{9.695}=0.412$

$X_{10,3}^{*}=\frac{3}{\sqrt{\left[3^{2}+2^{2}+4^{2}+3^{2}+2^{2}+3^{2}+3^{2}+3^{2}+4^{2}+3^{2}\right]}}=\frac{3}{\sqrt{94}}=\frac{3}{9.695}=0.309$

Untuk $C_{4}$ (Kehadiran)

$X_{1,4}^{*}=\frac{4}{\sqrt{\left[4^{2}+3^{2}+3^{2}+4^{2}+3^{2}+2^{2}+3^{2}+2^{2}+3^{2}+4^{2}\right]}}=\frac{4}{\sqrt{101}}=\frac{4}{10.049}=0.398$

$X_{2,4}^{*}=\frac{3}{\sqrt{\left[4^{2}+3^{2}+3^{2}+4^{2}+3^{2}+2^{2}+3^{2}+2^{2}+3^{2}+4^{2}\right]}}=\frac{3}{\sqrt{101}}=\frac{3}{10.049}=0.298$

$X_{3,4}^{*}=\frac{3}{\sqrt{\left[4^{2}+3^{2}+3^{2}+4^{2}+3^{2}+2^{2}+3^{2}+2^{2}+3^{2}+4^{2}\right]}}=\frac{3}{\sqrt{101}}=\frac{3}{10.049}=0.298$

$X_{4,4}^{*}=\frac{4}{\sqrt{\left[4^{2}+3^{2}+3^{2}+4^{2}+3^{2}+2^{2}+3^{2}+2^{2}+3^{2}+4^{2}\right]}}=\frac{4}{\sqrt{101}}=\frac{4}{10.049}=0.398$

$X_{5,4}^{*}=\frac{3}{\sqrt{\left[4^{2}+3^{2}+3^{2}+4^{2}+3^{2}+2^{2}+3^{2}+2^{2}+3^{2}+4^{2}\right]}}=\frac{3}{\sqrt{101}}=\frac{3}{10.049}=0.298$

$X_{6,4}^{*}=\frac{2}{\sqrt{\left[4^{2}+3^{2}+3^{2}+4^{2}+3^{2}+2^{2}+3^{2}+2^{2}+3^{2}+4^{2}\right]}}=\frac{2}{\sqrt{101}}=\frac{2}{10.049}=0.199$

$X_{7,4}^{*}=\frac{3}{\sqrt{\left[4^{2}+3^{2}+3^{2}+4^{2}+3^{2}+2^{2}+3^{2}+2^{2}+3^{2}+4^{2}\right]}}=\frac{3}{\sqrt{101}}=\frac{3}{10.049}=0.298$

$X_{8,4}^{*}=\frac{2}{\sqrt{\left[4^{2}+3^{2}+3^{2}+4^{2}+3^{2}+2^{2}+3^{2}+2^{2}+3^{2}+4^{2}\right]}}=\frac{2}{\sqrt{101}}=\frac{2}{10.049}=0.199$

$X_{9,4}^{*}=\frac{3}{\sqrt{\left[4^{2}+3^{2}+3^{2}+4^{2}+3^{2}+2^{2}+3^{2}+2^{2}+3^{2}+4^{2}\right]}}=\frac{3}{\sqrt{101}}=\frac{3}{10.049}=0.298$

$X_{10,4}^{*}=\frac{4}{\sqrt{\left[4^{2}+3^{2}+3^{2}+4^{2}+3^{2}+2^{2}+3^{2}+2^{2}+3^{2}+4^{2}\right]}}=\frac{4}{\sqrt{101}}=\frac{4}{10.049}=0.398$

Untuk $C_{5}$ (Skill)

$X_{1,5}^{*}=\frac{4}{\sqrt{\left[4^{2}+3^{2}+2^{2}+4^{2}+3^{2}+3^{2}+4^{2}+3^{2}+3^{2}+2^{2}\right]}}=\frac{4}{\sqrt{101}}=\frac{4}{10.049}=0.398$

$X_{2,5}^{*}=\frac{3}{\sqrt{\left[4^{2}+3^{2}+2^{2}+4^{2}+3^{2}+3^{2}+4^{2}+3^{2}+3^{2}+2^{2}\right]}}=\frac{3}{\sqrt{101}}=\frac{3}{10.049}=0.298$

$X_{3,5}^{*}=\frac{2}{\sqrt{\left[4^{2}+3^{2}+2^{2}+4^{2}+3^{2}+3^{2}+4^{2}+3^{2}+3^{2}+2^{2}\right]}}=\frac{2}{\sqrt{101}}=\frac{2}{10.049}=0.199$

$X_{4,5}^{*}=\frac{4}{\sqrt{\left[4^{2}+3^{2}+2^{2}+4^{2}+3^{2}+3^{2}+4^{2}+3^{2}+3^{2}+2^{2}\right]}}=\frac{4}{\sqrt{101}}=\frac{4}{10.049}=0.398$

$X_{5,5}^{*}=\frac{3}{\sqrt{\left[4^{2}+3^{2}+2^{2}+4^{2}+3^{2}+3^{2}+4^{2}+3^{2}+3^{2}+2^{2}\right]}}=\frac{3}{\sqrt{101}}=\frac{3}{10.049}=0.298$

$X_{6,5}^{*}=\frac{3}{\sqrt{\left[4^{2}+3^{2}+2^{2}+4^{2}+3^{2}+3^{2}+4^{2}+3^{2}+3^{2}+2^{2}\right]}}=\frac{3}{\sqrt{101}}=\frac{3}{10.049}=0.298$

$X_{7,5}^{*}=\frac{4}{\sqrt{\left[4^{2}+3^{2}+2^{2}+4^{2}+3^{2}+3^{2}+4^{2}+3^{2}+3^{2}+2^{2}\right]}}=\frac{4}{\sqrt{101}}=\frac{4}{10.049}=0.398$

$X_{8,5}^{*}=\frac{3}{\sqrt{\left[4^{2}+3^{2}+2^{2}+4^{2}+3^{2}+3^{2}+4^{2}+3^{2}+3^{2}+2^{2}\right]}}=\frac{3}{\sqrt{101}}=\frac{3}{10.049}=0.298$

$X_{9,5}^{*}=\frac{3}{\sqrt{\left[4^{2}+3^{2}+2^{2}+4^{2}+3^{2}+3^{2}+4^{2}+3^{2}+3^{2}+2^{2}\right]}}=\frac{3}{\sqrt{101}}=\frac{3}{10.049}=0.298$

$X_{10,5}^{*}=\frac{2}{\sqrt{\left[4^{2}+3^{2}+2^{2}+4^{2}+3^{2}+3^{2}+4^{2}+3^{2}+3^{2}+2^{2}\right]}}=\frac{2}{\sqrt{101}}=\frac{2}{10.049}=0.199$

Untuk $C_{6}$ (Loyalitas) 


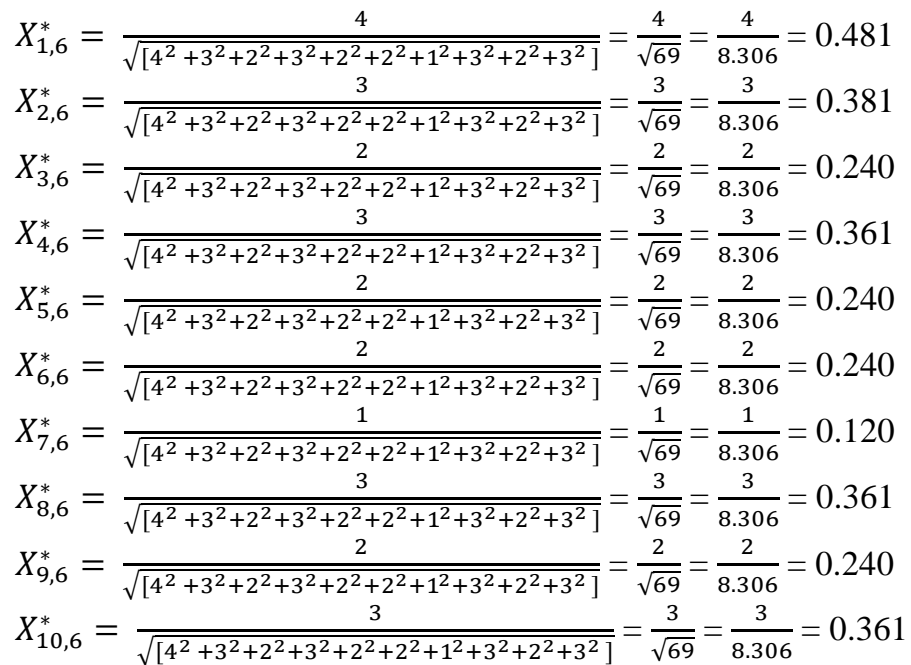

Untuk $C_{7}$ (Masa Kerja)

$X_{1,7}^{*}=\frac{7}{\sqrt{\left[7^{2}+5^{2}+4^{2}+3^{2}+2^{2}+4^{2}+2^{2}+4^{2}+6^{2}+5^{2}\right]}}=\frac{7}{\sqrt{200}}=\frac{7}{14.142}=0.494$

$X_{2,7}^{*}=\frac{5}{\sqrt{\left[7^{2}+5^{2}+4^{2}+3^{2}+2^{2}+4^{2}+2^{2}+4^{2}+6^{2}+5^{2}\right]}}=\frac{5}{\sqrt{200}}=\frac{5}{14.142}=0.353$

$X_{3,7}^{*}=\frac{4}{\sqrt{\left[7^{2}+5^{2}+4^{2}+3^{2}+2^{2}+4^{2}+2^{2}+4^{2}+6^{2}+5^{2}\right]}}=\frac{4}{\sqrt{200}}=\frac{4}{14.142}=0.282$

$X_{4,7}^{*}=\frac{3}{\sqrt{\left[7^{2}+5^{2}+4^{2}+3^{2}+2^{2}+4^{2}+2^{2}+4^{2}+6^{2}+5^{2}\right]}}=\frac{3}{\sqrt{200}}=\frac{3}{14.142}=0.212$

$X_{5,7}^{*}=\frac{2}{\sqrt{\left[7^{2}+5^{2}+4^{2}+3^{2}+2^{2}+4^{2}+2^{2}+4^{2}+6^{2}+5^{2}\right]}}=\frac{2}{\sqrt{200}}=\frac{2}{14.142}=0.141$

$X_{6,7}^{*}=\frac{4}{\sqrt{\left[7^{2}+5^{2}+4^{2}+3^{2}+2^{2}+4^{2}+2^{2}+4^{2}+6^{2}+5^{2}\right]}}=\frac{4}{\sqrt{200}}=\frac{4}{14.142}=0.282$

$X_{7,7}^{*}=\frac{2}{\sqrt{\left[7^{2}+5^{2}+4^{2}+3^{2}+2^{2}+4^{2}+2^{2}+4^{2}+6^{2}+5^{2}\right]}}=\frac{2}{\sqrt{200}}=\frac{2}{14.142}=0.141$

$X_{8,7}^{*}=\frac{4}{\sqrt{\left[7^{2}+5^{2}+4^{2}+3^{2}+2^{2}+4^{2}+2^{2}+4^{2}+6^{2}+5^{2}\right]}}=\frac{4}{\sqrt{200}}=\frac{4}{14.142}=0.282$

$X_{9,7}^{*}=\frac{6}{\sqrt{\left[7^{2}+5^{2}+4^{2}+3^{2}+2^{2}+4^{2}+2^{2}+4^{2}+6^{2}+5^{2}\right]}}=\frac{6}{\sqrt{200}}=\frac{6}{14.142}=0.424$

$X_{10,7}^{*}=\frac{5}{\sqrt{\left[7^{2}+5^{2}+4^{2}+3^{2}+2^{2}+4^{2}+2^{2}+4^{2}+6^{2}+5^{2}\right]}}=\frac{5}{\sqrt{200}}=\frac{5}{14.142}=0.353$

Untuk $C_{8}$ (Produktifitas)

$X_{1,8}^{*}=\frac{4}{\sqrt{\left[4^{2}+3^{2}+2^{2}+3^{2}+2^{2}+2^{2}+1^{2}+3^{2}+2^{2}+3^{2}\right]}}=\frac{4}{\sqrt{69}}=\frac{4}{8.306}=0.481$

$X_{2,8}^{*}=\frac{3}{\sqrt{\left[4^{2}+3^{2}+2^{2}+3^{2}+2^{2}+2^{2}+1^{2}+3^{2}+2^{2}+3^{2}\right]}}=\frac{3}{\sqrt{69}}=\frac{3}{8.306}=0.381$

$X_{3,8}^{*}=\frac{2}{\sqrt{\left[4^{2}+3^{2}+2^{2}+3^{2}+2^{2}+2^{2}+1^{2}+3^{2}+2^{2}+3^{2}\right]}}=\frac{2}{\sqrt{69}}=\frac{2}{8.306}=0.240$

$X_{4,8}^{*}=\frac{3}{\sqrt{\left[4^{2}+3^{2}+2^{2}+3^{2}+2^{2}+2^{2}+1^{2}+3^{2}+2^{2}+3^{2}\right]}}=\frac{3}{\sqrt{69}}=\frac{3}{8.306}=0.361$

$X_{5,8}^{*}=\frac{2}{\sqrt{\left[4^{2}+3^{2}+2^{2}+3^{2}+2^{2}+2^{2}+1^{2}+3^{2}+2^{2}+3^{2}\right]}}=\frac{2}{\sqrt{69}}=\frac{2}{8.306}=0.240$

$X_{6,8}^{*}=\frac{2}{\sqrt{\left[4^{2}+3^{2}+2^{2}+3^{2}+2^{2}+2^{2}+1^{2}+3^{2}+2^{2}+3^{2}\right]}}=\frac{2}{\sqrt{69}}=\frac{2}{8.306}=0.240$

$X_{7,8}^{*}=\frac{1}{\sqrt{\left[4^{2}+3^{2}+2^{2}+3^{2}+2^{2}+2^{2}+1^{2}+3^{2}+2^{2}+3^{2}\right]}}=\frac{1}{\sqrt{69}}=\frac{1}{8.306}=0.120$

$X_{8,8}^{*}=\frac{3}{\sqrt{\left[4^{2}+3^{2}+2^{2}+3^{2}+2^{2}+2^{2}+1^{2}+3^{2}+2^{2}+3^{2}\right]}}=\frac{3}{\sqrt{69}}=\frac{3}{8.306}=0.361$

$X_{9,8}^{*}=\frac{2}{\sqrt{\left[4^{2}+3^{2}+2^{2}+3^{2}+2^{2}+2^{2}+1^{2}+3^{2}+2^{2}+3^{2}\right]}}=\frac{2}{\sqrt{69}}=\frac{2}{8.306}=0.240$

$X_{10,8}^{*}=\frac{3}{\sqrt{\left[4^{2}+3^{2}+2^{2}+3^{2}+2^{2}+2^{2}+1^{2}+3^{2}+2^{2}+3^{2}\right]}}=\frac{3}{\sqrt{69}}=\frac{3}{8.306}=0.361$

Maka hasil yang diperoleh dari perhitungan diatas yaitu menghasilkan matriks ternormalisasi $X_{i j}^{*}$ seperti tabel 9 dibawah ini: 
Tabel 9. Hasil Matriks Ternormalisasi

$x_{i j}=\left|\begin{array}{llllllll}0.408 & 0.394 & 0.309 & 0.398 & 0.398 & 0.481 & 0.494 & 0.481 \\ 0.306 & 0.295 & 0.206 & 0.298 & 0.298 & 0.381 & 0.353 & 0.381 \\ 0.204 & 0.295 & 0.412 & 0.298 & 0.199 & 0.240 & 0.282 & 0.240 \\ 0.204 & 0.197 & 0.309 & 0.398 & 0.398 & 0.361 & 0.212 & 0.361 \\ 0.306 & 0.295 & 0.206 & 0.298 & 0.298 & 0.240 & 0.141 & 0.240 \\ 0.306 & 0.394 & 0.309 & 0.199 & 0.298 & 0.240 & 0.282 & 0.240 \\ 0.204 & 0.197 & 0.309 & 0.298 & 0.398 & 0.120 & 0.141 & 0.120 \\ 0.306 & 0.394 & 0.309 & 0.199 & 0.298 & 0.361 & 0.282 & 0.361 \\ 0.408 & 0.394 & 0.412 & 0.298 & 0.298 & 0.240 & 0.424 & 0.240 \\ 0.408 & 0.197 & 0.309 & 0.398 & 0.199 & 0.361 & 0.353 & 0.361\end{array}\right|$

3. Menentukan Nilai Optimasi dengan Bobot

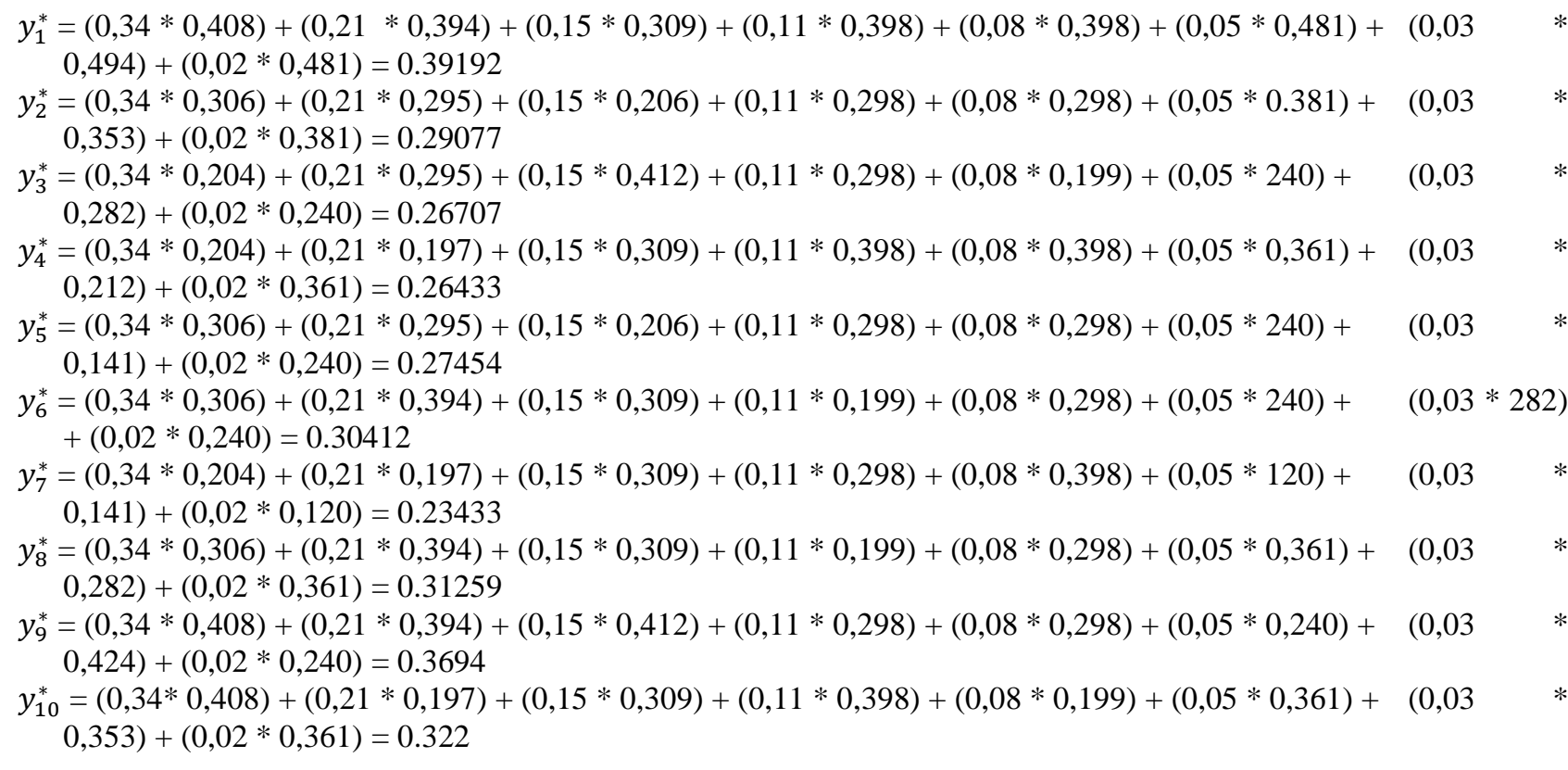
ini:

Jadi, hasil akhir dalam menentukan nilai optimasi dan menyertakan bobot dapat terlihat seperti tabel 10 dibawah

Tabel 10. Nilai Optimasi $\left(y_{i}^{*}\right)$

\begin{tabular}{cccc}
\hline Altenatif & Nama & Nilai $y_{i}^{*}$ & Peringkat \\
\hline $\mathrm{A}_{1}$ & Khairul Anhar & 0.39192 & 1 \\
$\mathrm{~A}_{2}$ & Vivi Elvina Simanjuntak & 0.29077 & 6 \\
$\mathrm{~A}_{3}$ & Rahmad Hidayat & 0.26707 & 8 \\
$\mathrm{~A}_{4}$ & Rudi Hermansyah Bako & 0.26433 & 9 \\
$\mathrm{~A}_{5}$ & Ricky Syahputra & 0.27454 & 7 \\
$\mathrm{~A}_{6}$ & Rudi Sidabutar & 0.30412 & 5 \\
$\mathrm{~A}_{7}$ & Chandra Mualim Putra & 0.23433 & 10 \\
$\mathrm{~A}_{8}$ & Muhammad Soufi & 0.31259 & 4 \\
$\mathrm{~A}_{9}$ & Moethar Situmeang & 0.3694 & 2 \\
$\mathrm{~A}_{10}$ & Agustin Rahmawati & 0.322 & 3 \\
\hline
\end{tabular}

Dari Tabel 10 terdapat hasil pengujian kesepuluh calon karyawan terbaik dan disimpulkan bahwa alternatif terbaik ialah yang di anggap layak menjadi karyawan terbaik yaitu Khairul Anhar dengan nilai optimasi sebesar 0.39192.

\section{KESIMPULAN}

Dari penelitian yang dilakukan dapat disimpulkan bahwa Multi Objective Optimization on the Basic of Ratio Analysis (MOORA) dapat digunakan dalam pemelihan Karyawan parking area terbaik di PT. Centrepark Citra Corpora. Dengan menggunakan metode tersebut dimana Sistem Pendukung Keputusan dapat digunakan sebagai alat bantu dalam menentukan Karyawan terbaik. Dan dalam hal ini faktor yang sangat mempengaruhi hasil dan menentukan Karyawan 
terbaik dengan menggunakan metode MOORA sehingga memperoleh nilai optimasi terbesar serta menghasilkan alternatif terbaik sebagai peringkat pertama.

\section{REFERENCES}

[1] H. Hertyana, "Sistem Pendukung Keputusan Penentuan Karyawan Terbaik Menggunakan Metode Saw Studi Kasus Amik Mahaputra Riau,” J. Intra-Tech, vol. 2, no. 1, pp. 73-82, 2018.

[2] A. Juanda and F. A. Sianturi, "Sistem Pendukung Keputusan Pemilihan Karyawan Tetap pada Trinity Teknologi Nusantara Dengan Metode Moora,” JIKOMSI [Jurnal Ilmu Komput. dan Sist. Informasi], vol. 3, no. 3, pp. 277$282,2021$.

[3] I. Hidayatulloh and M. Z. Naf'an, "Metode Moora Dengan Pendekatan Price-Quality Ratio Untuk Rekomendasi Pemilihan Smartphone," J. SINTAK, pp. 62-68, 2017.

[4] N. Lestari, J. Karman, and B. Santoso, "Komparasi Metode Weighted Aggregated Sum Product Assessment (WASPAS) dan Multi-Objective Optimization on The Basis of Ratio (MOORA) Dalam Penerimaan Dosen," J. Inf. Syst. Res., vol. 2, no. 2, pp. 138-147, 2021.

[5] Willem Karel Brauers and E. Kazimieras Zavadskas, "The MOORA method and its application to privatization in a transition economy," Control Cybern., vol. 35, no. 2, pp. 445-469, 2006.

[6] S. Manurung, "Sistem Pendukung Keputusan Pemilihan Guru Dan Pegawai Terbaik Menggunakan Metode Moora," Simetris J. Tek. Mesin, Elektro dan Ilmu Komput., vol. 9, no. 1, pp. 701-706, 2018.

[7] U. M. Method, "Sistem Pendukung Keputusan Pemilihan Buah Decision Support System for Choosing the Best Red Fruit," vol. 14, no. 1, pp. 55-64, 2021.

[8] J. S. Komputer, F. Handayanna, I. Purnamasari, K. Nusa, M. Tower, and K. C. Melayu, "Sistem Pendukung Keputusan Perekrutan Karyawan Online Untuk Penerimaan Karyawan Dengan Metode MOORA," J-SAKTI (Jurnal Sains Komput. dan Inform., vol. 4, no. September, pp. 487-498, 2020.

[9] T. Limbong et al., Sistem Pendukung Keputusan: Metode \& Implementasi. Medan: Yayasan Kita Menulis, 2020.

[10] D. Nofriansyah, Multi Criteria Decision Making. Yogyakarta: Deepublish, 2017.

[11] D. Nofriansyah, Konsep Data Mining Vs Sistem Pendukung Keputusan. 2015.

[12] R. D. Arista, S. Defit, and Y. Yunus, "MOORA sebagai SistemPendukung Keputusan Dalam Mengukur Tingkat Kinerja Dosen (Universitas Pembangunan Panca Budi Medan)," J. Inform. Ekon. Bisnis, vol. 2, no. 2019, pp. 104$110,2020$.

[13] A. T. Hidayat, N. K. Daulay, and Mesran, "Penerapan Metode Multi-Objective Optimization on The Basis of Ratio Analysis (MOORA) dalam Pemilihan Wiraniaga Terbaik," J. Comput. Syst. Informatics, vol. 1, no. 4, pp. 367-372, 2020.

[14] N. K. Daulay, B. Intan, and M. Irvai, "Comparison of the WASPAS and MOORA Methods in Providing Single Tuition Scholarships,” IJICS (International J. Informatics Comput. Sci., vol. 5, no. 1, pp. 84-94, 2021.

[15] J. Afriany, L. Ratna, S. Br, I. Julianty, and E. L. Nainggolan, "Penerapan MOORA Untuk Mendukung Efektifitas Keputusan Manajemen Dalam Penentuan Lokasi SPBU,” vol. 5, no. 2, pp. 161-166, 2018.

[16] Mesran, R. K. Hondro, M. Syahrizal, A. P. U. Siahaan, R. Rahim, and Suginam, "Student Admission Assessment using Multi-Objective Optimization on the Basis of Ratio Analysis (MOORA)," J. Online Jar. COT POLIPT, vol. 10, no. 7, pp. 1-6, 2017.

[17] A. D. Amanda, F. N. Arieni, and A. P. Windarto, "Penerapan Metode Multi Objective Optimization on The Basic of Ratio Analysis ( MOORA ) pada Pemilihan Masker Organik Wajah Berdasarkan Kriteria,” J. Sist. Komput. dan Inform., vol. 2, no. 3, pp. 283-288, 2021.

[18] Mesran, S. D. A. Pardede, A. Harapahap, and A. P. U. Siahaan, "Sistem Pendukung Keputusan Pemilihan Peserta Jaminan Kesehatan Masyarakat (Jamkesmas) Menerapkan Metode MOORA," Media Inform. Budidarma, vol. Vol 2, No, no. 2, p. hal 16-22, 2018.

[19] E. Astuti and N. E. Saragih, "Sistem Pendukung Keputusan Pemilihan Sekolah Terbaik dengan Metode Moora," J. Ilm. Inform., vol. 8, no. 2, pp. 136-140, 2020.

[20] M. Mesran, T. M. Diansyah, and F. Fadlina, "Implemententasi Metode Rank Order Cendroid (ROC) dan Operational Competitiveness Rating Analysis (OCRA) dalam Penilaian Kinerja Dosen Komputer Menerapkan (Studi Kasus: STMIK Budi Darma),” Pros. Semin. Nas. Ris. Inf. Sci., vol. 1, no. 0, p. 822, Sep. 2019.

[21] M. Mesran, J. Afriany, and S. H. Sahir, "Efektifitas Penilaian Kinerja Karyawan Dalam Peningkatan Motivasi Kerja Menerapkan Metode Rank Order Centroid (ROC) dan Additive Ratio Assessment (ARAS)," Pros. Semin. Nas. Ris. Inf. Sci., vol. 1, no. 0, pp. 813-821, Sep. 2019.

[22] Di. P. U. Samuel Damanik, "Implementasi Metode ROC (Rank Order Centroid) Dan Waspas Dalam Sistem Pendukung Keputusan Pemilihan Kerjasama Vendor,” KOMIK (Konferensi Nas. Teknol. Inf. dan Komputer), vol. 1, no. 1, pp. 242-241, 2020. 